\title{
Character Education in Developing the Careers of Children Special Needs in Vocational Providers School Inclusive
}

\author{
Mega Iswari ${ }^{1 *)}$ \\ ${ }^{123}$ Universitas Negeri Padang \\ $\equiv$ e-mail: megaiswari@yahoo.com
}

\begin{abstract}
This research aims to study and compile data is comprehensive, ranging from the new data and actual integrated on character education in developing the careers of children in need of special vocational education, then perform verification and validation data to identify where children in need of special vocational schools are there in having a good character in the development of his career as the blind children, deaf children and autistic children. They are capable of learning to follow suit with his talent and his interest in achieving careers in the future. Character education has always been integrated in every learning process in school either in a honesty, working, responsibility, confidence, persevering, meticulous and others. External research during the first year are learning implementation plan and the integrated learning materials on character education for individual learning in vocational secondary schools as education providers Inclusion in The City Of Padang.
\end{abstract}

Keyword: character education, career development, children Spesial needs, and Senior High School provider inclusion.

Copyright (C) 2018 IICET (Indonesia) - All Rights Reserved

Indonesian Institute for Counseling, Education and Therapy (IICET)

\section{INTRODUCTION}

Curriculum implementation activities 2013 demand teachers more professional and be more creative and innovative learning and assessment to do for the children in need special follow vocational education in secondary schools as Inclusion education providers. Inclusive education is the current education model for the children in need special formally expressed in a statement in June 1994 at the Salamanca World Conference that discusses about education for the children in need special. Inclusive is for allowing all children in need of special should learn together in the classroom regardless of any difficulties or differences in the children in need special and regular students. Opinion Stainback (1990:73) stated that the school is an inclusive school education providers that hold all the children in need special in the same class. This school provides educational programs that are worthy, challenging, but in accordance with the capacities and needs of each child in need, as well as special help and support that was provided to teachers so that children successfully study together with the students others. Sapon-Shevin Meanwhile (1995) suggests that the inclusive education is a system of educational services requires that children in need of special education are served at nearby schools, just like in regular classes together friends of her age. In the opinion of others, Sunanto, j. (2000:3), termed the inclusion education is conducting an education in which children who have the disorder (mild, moderate, or severe) and a normal child can learn together in public schools. For those who have trouble because the defect provided special assistance in regular classes with friends his age. 
Some children in need of special education can follow the inclusion in public school are the children who experience auditory abnormalities or also called deaf children or children with hearing impediments, whereas children who experience the disorder regular vision termed children who are blind or with vision barriers. Likewise with children who experience autism. Children who experience a third term this disorder are able to follow the processes of teaching and learning along with other normal students. When teachers of subjects experiencing difficulty in teaching and learning, then much needed cooperation between teachers of subjects with teachers supervising special education backgrounds, and can even learn with fellow peers commonly referred to also by peer tutors, so it can help the children in need of special education who come in regular school/inclusion.

Limitation that belongs to the children in need special, is not an obstacle to can follow the process of education in public schools. We can see in real time has many students or students who are blind, deaf or follow autism education at colleges like in ICU, UNS and UNP. This shows that when students who are blind are given opportunities and services adequate education, so they can be educated up to the college level and has even been there who are blind who has successfully become a doctoral education. The ability of the blind was not a coincidence but conceptually has been recognized by the experts of the blind students education i.e., Hardman, L, et al (1990:25) in one of his studies found that the condition of the blindness does not give impact on the development of fatalistic intelligentsia and the ability to follow a process of education and develop careers for the sake of the future.

Education inclusion or integrated education can be defined as a model organization of education in which children who have the disorder and regular students can learn together in public schools. For those who have difficulties in compliance defect on to provide special assistance. In the educational system is used with children in need of special terminology or simply ' Children with Special Education Need (Children with SEN)' as a replacement for the term disabled children or children is incredible. This meaning that every child has special needs either a permanent or not. this special needs can be distinguished into three, namely; (1) the needs of the individual; (2) special needs are exception and (3) the special needs of the public.

In connection with the change of the way of view of society towards children in several countries including in some communities in Indonesia, there is agreement that the educational system inclusive is a system of education that most deserves to be implemented. Sunanto $(2000 ; 4)$ explains some of the reasons education inclusion as a model of education for exceptional children, namely: (1) all children have the right to learn together. (2) children should not be treated with discriminating separated from other groups because of the defect. (3) there is no legal reason to separate education for exceptional children, because every person has its advantages and disadvantages of each. (4) Many research results suggest that academic achievement and social son remarkable at school integration better than on school segregation. (5) there is no teaching in school segregation that can not be done in public.

(6) Through the commitment and good support, integrated education is more efficient in the use of learning resources.

(7) all children need an education that helps them evolve to live in normal society and

(8) just a potentially integrated education system to reduce the sense of friendship, build a sense of mutual concern to appreciate and understand.

Learning is an activity the teacher are hard-wired to make students learn actively, which places emphasis on the provision of learning resources, and is the process of interaction with educators and learners learning resources in a learning environment (UUSPN No. 20 th. 2003). Interaction between students and teachers through various means and media atmosphere, so that learners can achieve the goal of education. Learning is an activity of educators are hard-wired to make students learn actively, which places emphasis on the provision of learning resources (Dimyati and Mudjiono, 1999), and, is the process of interaction with learners and educators learning in a learning environment (UUSPN No. 20 th. 2003). The interaction between learners and educators through various means and media atmosphere, so that learners can achieve the goal of education. The interaction relationship of educators and learners are very special and unique effort. Special because with education that is prepared to live a human life. Unique because it contains special features not found on other activities (Prayitno, 2005). The students learn to get something new, useful as a development 
of panca, noting what was obtained so that it can be carried everywhere, and apply what is learned and recorded it in behavior and life (Prayitno, 2008).

The learning process is the interaction of the conscious purpose between educators and learners, which means that the interactions that have been established for certain purposes at least something is the achievement of the learning objectives have been formulated. The interaction process is according to (Prayitno, 2005), has two principal content i.e. the Authority (hi-touch) and kewiyatan (hi-tech). Authority (Gezag) comes from the word meaning zeggen said. Who's words had the force of law against everyone else, means has the authority of others (m. Ngalim Purwanto, 2003). The authority is a ' tool ' in education between personal connect learners with educators in educational situations which is a social relation between the two. With the authority of educators ' entering ' private learners, and learners ' directs ' himself to educators. The Authority include;

(a) recognition,

(b) to compassion and tenderness,

(c) reinforcement,

(d) briefing,

(e) action emphatic that educate, and

(f) example that educate.

Kewiyataan comes from the word 'wiyata', which means teaching. 'Kewiyataan' is a great learning tool for educators organized the realization process of the achievement of the objectives of education by learners. Kewiyataan include mastery of educators over curriculum): a, b), c) learning environment AIDS learning, d) model of learning, and learning outcomes assessment e) (Prayitno, 2005).

A learning model of inclusion is a form of learning that is imaged from beginning to end is typically presented by teachers in the classroom by observing the characteristics of the students who have their respective areas, whereas in a learning There is a strategy of achievement of competence of learners with the approaches, methods and techniques of instruction. But in this case there is no model the most effective learning for all subjects or for all materials. The learning model applied to the selection of the teachers in the classroom, among others, consider a few things:

(1) learning objectives,

(2) nature of the subject matter,

(3) availability of facilities,

(4) conditions of the learners, and

(5) allocation of time available.

A good learning model has characteristics that is;

(1) the existence of intellectual-emotional involvement through student activities experience analyzing, done and the formation of attitude.

(2) existence of student participation is actively and creatively for the implementation of the learning model.

(3) teachers act as facilitators, coordinators, mediator, and to motivator learning activities of students, and

(4) using a variety of methods, tools and instructional media.

Learning models for the children in need special are:

(1) the contextual teaching and learning, namely the concept of learning which encourages teachers to connect between the material with real-world situations.

(2) cooperative learning) models, namely learning that give priority to the cooperation among students to achieve learning goal

(3) models of individual learning, namely learning that focuses on self help and guidance on individual students

(4) classical learning models), namely: the teacher teaches a number of learners, usually between 30 up to 40 students in a room.

(5) multisensori learning model and 


\section{(6) learning behavior modification model}

The purpose of education as learning outcomes is the Internalization and accumulation of knowledge, skills, and competencies that affection is achieved through a structured educational process and includes a specific expertise/science or work experience. The purpose of education can not be ' Aims, Goals, and Objectives ', which Aims at showing the general direction of the curriculum reflects the quality level of the educational objectives based on the view of filisofis and psychological or the expected life, goals is the purpose of obtained from the results of the learning process according to a school system and objectives is the purpose of a unit or a more specific subject matter after the learners follow a lesson.

In Act No. 2 of 1989 Year of national educational systems is the intellectual life of the nation and develop the whole Indonesia man, the man of faith and piety towards God Almighty and ethical sublime, have knowledge and skills, physical and spiritual health, a steady and independent personality and sense of responsibility of civic and nationality. Prayitno (2005:13) argued: based upon humanity, educational purposes refer to the purpose of human life, which is none other than the joys of life world and the hereafter. The purpose of education that is both thorough and public or explain for directional human humanity, through the realization of the development dimensions of humanitarian as well as the five sense of them . Refer to the dignity and the dignity of human beings, the purpose of education is normative, because human rights are normative. Any efforts that are inconsistent with or contrary to human rights education efforts, is not?

The purpose of normative education, became the focus of a human is involved in educational activities. There are two parties who are directly involved in this activity are the learners and educators. Both these parties upheld human rights, human dimension, and the five senses. The two parties also was focused on the purpose of education, but at a different position. Educators are in a position to encourage the development of objectives and the formulation of ' delivered ' to learners, while the position of the students in the position of trying to achieve a goal (Prayitno, 2007).

The values of character is how to think and behave that became the hallmark of every individual to life, and cooperate in the family environment, the community, the nation and the State, while the character is personality, behave, temper and a calm. Individuals who are of good character are individuals who can make a decision and is ready to account for any damage done. The character is composed of several interrelated behavior i.e. know the meaning of goodness willing to do good and real conduct that is good. The third thing it boils down to a moral life and moral maturity of the individual.

Based on Pancasila and the 1945 CONSTITUTION is actually effected by character education embodies a national consensus. The consensus further clarified through law No. 20 of 2003 year of the national education system, on article 3, which States that national education serves to develop the ability to form character and the civilization of a nation dignity in the framework of the intellectual life of the nation. National education aimed at the development of potential learners in order to become a man of faith and piety to God Almighty, precious, healthy, have learned, accomplished, creative, independent, and become citizens of a democratic and responsible for various aspects of life.

Through character education teachers can guide and direct the students during the learning process in schools. The application of character in every learning process capable of providing stimuli specifically on regular students or students in need of special, they is able to carry out character values wherever they are, either while learning in school and in a variety of situations with anyone they face.

In the implementation of the values of the character was still a lot of teachers who have yet to carry out cultivation of character values to students because many teachers completing tasks of teaching so that implementation has not been planting value character in learning. When the value of the characters can be embedded ranging from environment and everyday experiences of students in the learning process in schools. Neither with the various forms of the game that could give the impression that in any learning process will be fun spots for you and for students. In accordance with the curriculum focuses more on 2013 character education for all subjects.

Character development in learning can be done through conditioning and example of positive attitudes. Conditioning and this example should already animates each stage of learning activities. In this case, the educator provides space and facilities to the students so that is able to develop scientific attitudes. 
To achieve the goal of integrated learning character Educators should know the stages of educating character. At least through three stages of learning that writers have termed with the 3P, is: thinking, feeling and action:

(1). Stages of thought, are providing knowledge about the characters. At this stage of educators trying to fill in reason, logic and the ratio of learners so that the learners are able to distinguish positive characters (good) with negative characters (not good). The students were able to understand logically and rationally the importance of positive character and dangers posed a negative character.

(2) the stage of feeling, are loving and needs a positive character. At this stage of educators trying to touch the heart and soul of the learners are no longer makes sense, ratio and logic. It is hoped this will appear on the stage of the consciousness of the heart will be the importance of positive character, which in the end will bring forth the urge/desire is strong from the inside to practice the character in her everyday.

(3) the stage of works on this stage urge/desire in the student to practice positive character is manifested in the everyday life. So that students will be more polite, friendly, loving, diligent, honest, and the more pleasant, soothing views and the hearts of those who see it and interact with it.

Characteristic education aims to develop potential);

(1) heart/conscience/effective students as human citizens who have the character values of the nation.

(2) developed the habits and behaviour of learners are commendable and aligns with the universal values and religious cultural traditions.

(3) embed the soul of discipline and responsibility of students as the next generation.

(4) develop the ability of students to become independent of the human, creative and insightful,

(5) develop environmental life of the school as a learning environment that is safe, honest, full of creativity and friendship as well as with a sense of nationality and full power. (Hardiknas, May 20, 2011). Through some of these goals will enable students to develop and infuse the character values in everyday life.

Character education function is to:

(1) developed the basic potential in order to be good-hearted, good minded and behave well.

(2) strengthen and establish the behavior of the multi cultural nation (reinforce behavior which is already very good).

(3) increase competitive nation civilization in the Association world (less cultural filters in accordance with the cultural values of the nation).

In recent years many communities are demanding an increase in the intensity and quality of the implementation character education in institutions of formal education. These demands occur due to a growing phenomena on the rising juvenile delinquency in the community environment. Such children do not know the ethics of manners of juvenile delinquency, rape, gave birth to a child outside of marriage, the use of illegal drugs, as well as various mass fights other delinquency which is very troubling. Thus the institution formal and informal education as well as education in the family expected to increase its role in the formation of the personality of the child through character education. As well as increase the faith and piety to God.

During this time our education has provided assessment in subjects related to values education, but not yet in total measure wholly personal. Thus the implementation of values education in school will need to use a variety of methods that can touch the totality of children in order to make the emotional quality of the character of the nation in the hope to future generations.

Character education in it include manners, values, norms, and moral. In accordance with his nature as human beings who are free and independent, in the moral value of choosing independence and have a norm which provided guidelines in do, behave in the life of society. In learning the value of manners and morals, norms,. In this case it is generally something with regard to good behavior conceptually related to ethics. Through character education is expected community can maintain and develop his true identity in the midst of the current globalization, so that the community remain ready and confident that its still growing, although other values entered because the current rapid globalization. Through education are expected to sort and retrieve the values that come with the intention of enriching the cultural communities concerned. This means that the education we are able to give birth to a positive attitude towards accommodating the changes in force and continues to grow. 
UNESCO (2003.101-105) states that in the future teachers are required to master and be able to utilize communication and information technology and become a facilitator who is able to teach children to find something. To enhance ethical and practical abilities, character education requires close coordination with other fields. Teachers need to guide children with special needs to develop self-awareness and self-discipline and instill ethical character or behavior through practice and examples presented by the teacher themselves every learning process.

\section{METHOD}

The study used a descriptive approach to qualitative research related to the objective conditions of the Children in need Special Vocational secondary school inclusion. Further research was designed by the research development. This is due to the working steps of research that started with the beginning of shooting data describing the situation and analyze the data based on the study of literature. Then formulated the Integrated character of the value of Planting Model on Learning in VOCATIONAL education providers inclusion. This first year of the research study and gather data in a new, comprehensive and actual interaction of the six components of the process of education (curriculum, educators, learners, infrastructure, technology and learning media, system assessment) for secondary education, and then verifying and validation data to identify where the occurrence of botleneck in the process of integrated learning, character, through indeep study. Period produce the draft indicators for the integration of the learning materials with character in a vocational high school. The resulting outer form of the syllabus, the learning plan, worksheet, handout. and rubric assessment

\section{RESULT AND DISCUSSION}

Based on the results of research it turned out that the number of secondary schools and vocational education providers inclusion in Padang city there are several vocational secondary school for the school year - i.e. 2016/2017 - 4th, 6, SMK N 7, and SMK N 8 with a total number of 56 students of SMK Negeri scattered people 4 as much as 18 people, SMK Negeri 6 as many as 27 people, SMK Negeri 8 people, 7 SMK Negeri 8 as much as 3 people. Consisting of children who are blind, deaf, learning and slow child autistic

School anat inclusive education providers in SMK Negeri Padang education inclusion education providers is that models moderate. Moderate model is known for its mainstreaming models. Mainstreaming education model is a model that combines the education for children in need of special education. Learners in need specifically incorporated into regular classes only for a short time only. His philosophy remains inclusive education, but in practice the children in need special provided a variety of alternative services in accordance with their capabilities and needs.

Children in need special can move from one form to another form, such as:

(1) the form of the regular classes full, Children in need of special study with other children (normal) all day in regular classes with the use of curriculum the same.

(2) the form of the regular classes with Children in need special cluster, to study with other children (normal) in regular classes in the special group.

(3) the form of the regular classroom with pull out, Children in need of special study with other children (normal) in regular classes but in certain times withdrawn from regular classes to the source to learn with a teacher supervisor special (GPK).

(4) the form of regular classes with cluster and pull out, Children in need of special study with other children (normal) in regular classes in the special group, and in certain times withdrawn from regular classes to the source to learn together with the teacher Special tutors.

(5) special classes with various forms of integration, Children in need of special study in special classes in regular schools, but in certain areas can learn together with other children (normal) in regular classes.

(6) the form of the full specialized classes in regular schools, Children in need of special study in special classes in regular schools. 
Thus, inclusive education as in the above model does not require that all children in need of special were in regular classes at any time with all subjects (full inclusion). This is due to some children in need special could be on special classes or therapy with a fairly heavy abnormalities gradations. Even for the children in need special abnormalities weight gradations, it might be a lot more time being in special classes in regular schools. Problems that arise in implementing the educational inclusion based on the perceptions of teachers, in terms of: the main problem Categories that many teachers complain about is the lack of a special Companion Teacher (GPK) of $27.39 \%$, lack of teacher's competence in dealing with HER as much as $19.64 \%$, teachers ' difficulty in teaching and learning activities (MBC) as much (17.86\%), a lack of understanding about HER teacher and school Inclusion as much as education providers $(16.67 \%)$, educational background of teachers that is not appropriate (5.95\%), load the ministrasi a.d. more weight for the gurus $(5.36 \%)$, lack of patience in the face of HER teacher $(2.39 \%)$ and teachers had trouble with parents $(1.78 \%)$.

Teachers have complained that less understand characteristics in dealing with HER. This is caused due to a lack of understanding about HER teacher so that teachers of the difficulty in teaching and learning activities. It is also supported by the fact that there are some teachers who have the educational background did not match and the lack of Special Escort Teachers so the more adds to the workload of the teachers who are heavy burden of administration as well as the burden of teaching it is also indirectly make an impact on how teachers deal with students in school is not the maximum in addition teachers are also faced with the problems of HER different and require different handling.

Results of the study stated that schools and teachers also have yet to figure out how the implementation of the Organization of the education of vocational high school inclusion in accordance with the existing rules. The study results also show that many of the issues that arose related implementation of school inclusion in terms of teachers, students, parents, schools, communities, Governments, and infrastructure is lacking, and the lack of cooperation from various parties so the impact is less the maximum implementation of the school inclusion.

through character education can shape children in need of special character and value of the sublime. Therefore, in order to be successful character education with good example, it is necessary from all sides, there is a good cooperation between parents, educators, and the public, there is a continuity between education held at home, in school, and in community, and learning should be organized with methods which touch the totality of emotional child.

A variety of approaches to character education development have the aspect of a different emphasis. The approach used in the implementation of character education is a mixed approach with an emphasis on approach to planting manners because both have the same objective essence. Namely instilling social values in children. Educational process varies, making it more interesting and not boring. Whereas the characteristic Education aims to develop potential), 1 heart/conscience/effective students as human citizens who have the character values of the nation. 2) developed the habits and behaviour of learners are commendable and aligns with the universal values and religious cultural traditions. 3) embed the soul of discipline and responsibility of students as the next generation. 4) develop the ability of students to become independent of the human, creative and insightful, 5) develop environmental life of the school as a learning environment that is safe, honest, full of creativity and friendship as well as with a sense of nationality and full power. (Hardiknas, May 20, 2011). Through some of these goals will enable students to develop and infuse the character values in everyday life.

While character education function is to: 1) developed the basic potential in order to be good-hearted, good minded and behave well. 2) strengthen and establish the behavior of the multi cultural nation (reinforce behavior which is already very good). 3) increase competitive nation civilization in the Association world (less cultural filters in accordance with the cultural values of the nation).

While another problem faced in the implementation of curriculum 2013 because several factors as follows: 1 . The difficulty of changing the mindset of teachers, 2 . changes in the process of learning from teacher centered to student centered, 3. the low moral, cultural, spiritual reading and researching. 4. lack of mastery of IT By 5. weak mastering the field of administration, 6. the tendency of teachers who emphasize the cognitive aspect more. Whereas, should the teacher must also provide the same portion on the affective and 
psychomotor. 7. There are still many teachers who do not yet want to be learners. Whereas, 8. a teacher is required to continue to add their knowledge and broaden his insights, especially after the enactment of the curriculum is 2013. In essence this demanding 2013 curriculum teachers more creative and innovative in the teaching process, as always a novelty will get rejection because it was comfortable with the learning process that's been done before, it's still an awful lot of the school has not used the curriculum 2013 for reasons still not capable, especially schools that are in the area.

\section{CONCLUSION}

The implementation of character education in vocational middle schools directly integrated in every learning at school. So that children in need of special education in the schools that follow the education providers of inclusion has a character that fits the culture and values that apply. But the problems that arise between one another when examined further would be relevant from both the problems of teachers, students, school, community, or Government. The first related the problems of teachers, teachers have complained that the lack of competence in dealing with HER. This is caused due to a lack of understanding about HER teacher, the teacher is the difficulty in teaching and learning activities. It is also supported by the fact that there are some teachers who have the educational background did not match and the lack of Special Escort Teachers so the more adds to the workload of the teachers who are heavy burden of administration as well as the burden of teaching it is also indirectly make an impact on how teachers deal with students in school is not the maximum. The study results also show that many of the issues that arose related implementation of school inclusion in terms of teachers, students, parents, schools, communities, Governments, and infrastructure is lacking, and the lack of cooperation from various parties so the impact is less the maximum implementation of the school inclusion. The success of the school inclusion need to involve many parties. School inclusion is a process which involves all school staff and students to its development like how organized the students approach, the role of the teaching staff, the approach in teaching and curriculum. The school should also cooperate with the community school as a teacher, a teacher accompanying classes, parents, students, school administrative team, and the school community to maximize the performance of teachers.

On the advice of other researchers as well as the Government can focus on solving problems related to teachers, such as increased understanding and competence of HER teacher characteristics because the teacher is the spearhead in implementing education characters in school inclusion education providers. The expectation if a teacher already understands and is able to carry out learning in school education providers inclusion in his school, teachers can transmit his knowledge to the community through good parenting parents caregivers from $\mathrm{ABK}$ or parents from Non $\mathrm{ABK}$ In expected Government have responsibility for professional development/improvement of the competence of teachers in understanding the ABK provide GPK.. This indicates that the actual school can also grow the improved quality of schools through teachers and the parties involved. Schools also have obligations in the enhancement of awareness of society with the support of various his special party Government.

\section{REFERENCE}

Dimyati dan Mujiono (1999). Belajar dan Pembelajaran. Jakarta: Rinek Cipta

Prayitno. (2005). Sosok Keilmuan Pendidikan. Fakultas Ilmu Pendidikan Pasca Sarjana, Universitas Negeri Padang

Prayitno. (2007). Ilmu Pendidikan Ilmunya Para Pendidik. Makalah pada Seminar Internasional Kependidikansdan Temu Nasional FIP/JIP se Indonesia di Menado, 21-23 Agustus 2007.

Prayitno. (2008). Sumber Belajar yang Mendidik.. Pasca Sarjana, Universitas Negeri Padang

Shapon-Shevin, M. (2007) Widening the Circle. The Power of Inclusive Classroom. Beacon Press. Boston

Steinback, William. \& Stainback, Susan. 1990.Support Networks for Inclusive Schooling : Independent Integreted Education. Baltimore: Paul H. Brooks

Sunanto J. (2004) Mengharap pendidikan Inklusi ( Makalah ) Bandung PLB FIP UPI Bandung 